\title{
Involvement of $\mu$-Receptor in Endogenous Opioid Peptide-Mediated Inhibition of Acetylcholine Release From the Rat Stomach
}

\author{
Kunihiko Yokotani and Yoshitsugu Osumi \\ Department of Pharmacology, Kochi Medical School, Nankoku, Kochi 783-8505, Japan \\ Received May 28, 1998 Accepted July 13, 1998
}

\begin{abstract}
We examined the effect of endogenous opioid peptides on vagally evoked release of acetylcholine (ACh) from the isolated, vascularly perfused rat stomach. The vagus nerves were electrically stimulated twice at $2.5 \mathrm{~Hz}$ for $2 \mathrm{~min}$, and test substances were administered during the second stimulation. $\beta$-Endorphin $\left(10^{-7}\right.$ and $\left.3 \times 10^{-7} \mathrm{M}\right)$, an endogenous nonselective agonist of $\mu$-receptors, inhibited the release of ACh. However, [Leu ${ }^{5}$-enkephalin, an endogenous nonselective agonist of $\delta$-receptors, and $\mathrm{U}-50488$, a $\kappa$-receptor agonist, had no effect at a higher dose of $10^{-6} \mathrm{M}$. $\beta$-Endorphin-induced inhibition was abolished by naloxone. Endomorphins 1 and $2\left(3 \times 10^{-7}\right.$ and $\left.10^{-6} \mathrm{M}\right)$, endogenous selective agonists of $\mu$-receptors, also inhibited the release of ACh. These results suggest that the $\mu$-receptor is involved in the endogenous opioid peptide-induced inhibition of the release of ACh from the rat stomach.
\end{abstract}

Keywords: Acetylcholine release, Stomach, $\mu$-Opioid receptor

Opiates have long been recognized as having a potent effect on gastrointestinal function. With the demonstration of specific opiate receptors and the subsequent discovery of endogenous opioid peptides such as enkephalin, $\beta$-endorphin and dynorphin, new light has been cast on the function of endogenous opioid peptides in the gastrointestinal tract. Thereafter, several types of opioid receptors have been distinguished, the best documented of which are now termed $\mu, \delta$ and $\kappa$. The presence of opioid-peptides $(1,2)$, messenger RNAs of opioid peptide precursors $(3,4)$ and opioid receptors $(5-7)$ are found mainly in the myenteric and submucosal plexus of the gastrointestinal tract, suggesting roles of endogenous opioid peptides in gastrointestinal physiology. In the present study, we examined the effect of opioid peptides and antagonist on the release of acetylcholine (ACh) from the isolated, vascularly perfused rat stomach.

Male Wistar rats weighing about $350 \mathrm{~g}$ were fasted overnight before experiments. Details of the experimental procedures were previously described (8). Briefly, under urethane anesthesia, a cannula was inserted into the celiac artery and modified Krebs-Ringer solution $\left(\mathrm{pH} 7.4,37^{\circ} \mathrm{C}\right)$ bubbled with a mixture of $95 \% \mathrm{O}_{2}-5 \% \mathrm{CO}_{2}$ was perfused at a flow rate of $4 \mathrm{ml}$ per min. Modified KrebsRinger solution contained $117.5 \mathrm{mM} \mathrm{NaCl}, 4.7 \mathrm{mM} \mathrm{KCl}$, $2.4 \mathrm{mM} \mathrm{CaCl}_{2}, 1.1 \mathrm{mM} \mathrm{MgCl}_{2}, 1.1 \mathrm{mM} \mathrm{NaH}_{2} \mathrm{PO}_{4}, 25 \mathrm{mM}$ $\mathrm{NaHCO}_{3}, 11.1 \mathrm{mM}$ glucose, $0.05 \%$ bovine serum albu- min and $100 \mu \mathrm{M}$ physostigmine. The right and left vagus nerves were carefully dissected out and the esophagus, duodenum, spleen, pancreas and aorta removed. Then the vascularly perfused stomach was kept in a chamber prewarmed at $37^{\circ} \mathrm{C}$. After an equilibration period of 60 min, each 2-min effluent from the portal vein was collected in chilled tubes containing $200 \mathrm{pmol}$ of isopropylhomocholine, an internal standard, and $250 \mu \mathrm{l}$ of $1 \mathrm{M}$ phosphoric acid. The vagus nerves were stimulated twice with square-wave pulses at $2.5 \mathrm{~Hz}$ (supramaximal intensity, $10 \mathrm{~mA}$; duration, $2 \mathrm{msec}$ ) for $2 \mathrm{~min}$, once at $4 \mathrm{~min}$ and again at $30 \mathrm{~min}$ after the beginning of sampling. The perfusion medium containing test substances was changed 14 min before the second vagal stimulation. The first and second release of $\mathrm{ACh}$ above the basal level induced by vagal stimulation was denoted $S_{1}$ and $S_{2}$, respectively. The effects of test substances were expressed as the ratio $S_{2}$ to $S_{1}$. The following drugs were used: $\beta$-endorphin, endomorphin-1 and endomorphin-2, [Leu $\left.{ }^{5}\right]$ enkephalin (Peptide Institute Inc., Osaka); U-50488 (Research Biochemicals Incorporated, Natick, MA, USA).

$\mathrm{ACh}$ in the perfused medium was measured by highperformance liquid chromatography followed by enzyme reaction and electrochemical detection (8). The analytical conditions were as follows: mobile phase, 0.1 $\mathrm{M} \mathrm{Na} \mathrm{HPO}_{4}$ (pH 8.5), $300 \mathrm{mg} / 1$ sodium $l$-decanesulfonate and $65 \mathrm{mg} / 1$ tetramethylammonium chloride at a 
flow rate of $1.0 \mathrm{ml} / \mathrm{min}$; a styrene polymer column (ACGEL; Eicom Co., Kyoto), a post-column enzyme reactor (AC-Enzympak, Eicom Co.) maintained at $34^{\circ} \mathrm{C}$; and an electrochemical detector (ECD-100, Eicom $\mathrm{Co}$.) equipped

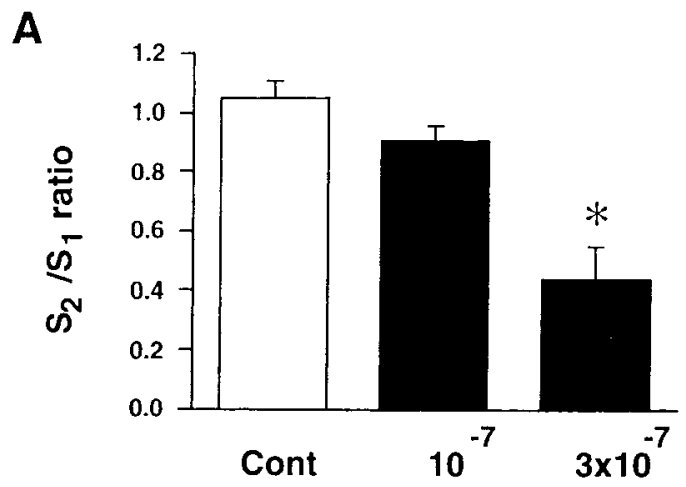

B

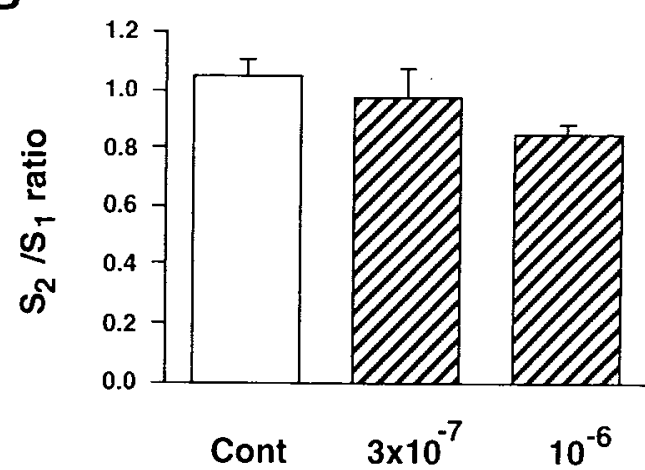

C

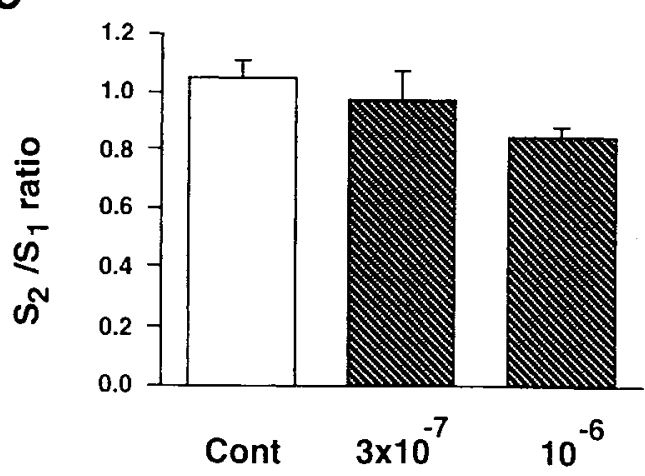

Fig. 1. Effects of $\beta$-endorphin (A), [Leu']-enkephalin (B) and U50488 (C) on the release of ACh from the isolated rat stomach in vitro. The right and left vagus nerves were stimulated twice at $2.5 \mathrm{~Hz}$ for $2 \mathrm{~min}$. The first stimulation was carried out in the normal medium and the second stimulation was carried out in the medium containing test substances described above. The effects of test substances were expressed as the ratio $S_{2}$ to $S_{1} . A$ : control (Cont) $(\mathrm{n}=6) ; 10^{-7} \mathrm{M} \beta$-endorphin $(\mathrm{n}=5) ; 3 \times 10^{-7} \mathrm{M} \beta$-endorphin ( $\left.\mathrm{n}=5\right)$. B: control (cited from Fig. $1 \mathrm{~A}$ ); $3 \times 10^{-7} \mathrm{M}$ [Leu ${ }^{5}$-enkephalin $(n=5) ; 10^{-6} \mathrm{M}\left[\mathrm{Leu} \mathrm{u}^{5}\right]$-enkephalin $(\mathrm{n}=5)$. C: control (cited from Fig. 1A); $3 \times 10^{-7} \mathrm{M} \mathrm{U}-50488(\mathrm{n}=5) ; 10^{-6} \mathrm{M} \mathrm{U}-50488(\mathrm{n}=5)$. Values are each a mean \pm S.E.M. *Significantly different from the control $(\mathrm{P}<0.05)$ (analyzed by one-way ANOVA followed by post hoc analysis with the Bonferroni method for comparing a control with all other means). with a platinum electrode, $+450 \mathrm{mV}$ against a $\mathrm{Ag} / \mathrm{AgCl}$ reference electrode. The amount of $\mathrm{ACh}$ was calculated from the peak height relative to isopropylhomocholine. The lowest detectable amount was 0.5 pmol.

The total tissue content of ACh was $21.3 \pm 0.4 \mathrm{nmol}$ per stomach $(\mathrm{n}=64)$. The basal release of $\mathrm{ACh}$ was $0.07 \pm$ $0.02 \%$ of its tissue content, and the evoked release above the basal level by the first vagal stimulation $(2 \mathrm{~min}$ ) was $0.98 \pm 0.15 \%$ of its tissue content. Repetitive stimulation of the vagus nerves evoked a consistent and reproducible increase in the release of ACh (Fig. 1A). $\beta$ Endorphin, a nonselective agonist of $\mu$-receptors with a weak agonistic activity for $\delta$-receptors, substantially reduced the release of $\mathrm{ACh}$ at $3 \times 10^{-7} \mathrm{M}$. In contrast, $\left[\mathrm{Leu}^{5}\right]$ enkephalin, a nonselective agonist of $\delta$-receptors with a weak agonistic activity for $\mu$-receptors, and $U$ 50488 , a $\kappa$-receptor agonist, had no effect even at a higher concentration of $10^{-6} \mathrm{M}$ (Fig. 1: $\mathrm{B}$ and $\mathrm{C}$ ). This concentration seems to be enough to examine the effect of $\left[\mathrm{Leu}^{5}\right]$ enkephalin on the release of $\mathrm{ACh}$ in the present study, since this peptide substantially reduces the release of ACh from rat brain slice at $10^{-6} \mathrm{M}(9)$. $\beta$-Endorphin $\left(3 \times 10^{-7} \mathrm{M}\right)$-induced reduction of $\mathrm{ACh}$ was abolished by naloxone $\left(10^{-5} \mathrm{M}\right)$ (Table 1). Naloxone itself had no effect on the basal release of ACh. From these results, it seems likely that $\beta$-endorphin inhibits the release of $\mathrm{ACh}$ from the rat stomach by activation of $\mu$-receptors. In the guinea pig ileum, activation of $\mu$ - and $\kappa$-receptors has been shown to inhibit the release of ACh $(10,11)$.

Recently, endomorphin-1 and endomorphin-2 isolated from bovine brain have been shown to have a high affinity

Table 1. Effect of naloxone on $\beta$-endorphin-induced inhibition of the release of $\mathrm{ACh}$ from isolated perfused rat stomach

\begin{tabular}{ccccc}
\hline \multicolumn{2}{c}{ Treatment } & & $\mathrm{N}$ & $\mathrm{S}_{2} / \mathrm{S}_{1}$ \\
\cline { 5 - 5 } Antagonist & Agonist & & \\
\hline$(-)$ & $(-)$ & 6 & $1.06 \pm 0.06^{\mathrm{a}}$ \\
$($ Vehicle alone) & & & \\
$(-)$ & $\beta$-Endorphin & 5 & $0.46 \pm 0.09^{\mathrm{b}, *}$ \\
Naloxone & $(-)$ & 4 & $1.13 \pm 0.04$ \\
Naloxone & $\beta$-Endorphin & 4 & $1.19 \pm 0.14$ \\
\hline
\end{tabular}

$\beta$-Endorphin, $3 \times 10^{-7} \mathrm{M}$; Naloxone, $10^{-5} \mathrm{M}$. The right and left vagus nerves were stimulated twice at $2.5 \mathrm{~Hz}$ for $2 \mathrm{~min}$. The first stimulation was carried out in the normal medium and the second stimulation was carried out in the medium containing the test substances described above. The effects of test substances were expressed as the ratio $S_{2}$ to $S_{1}$. Values are each a mean \pm S.E.M. ${ }^{a, b}$ Data were cited from Fig. 1A. *Significantly different from the control $(\mathrm{P}<0.05)$, analyzed by one-way ANOVA followed by post hoc analysis with Dunn's procedure as a multiple comparison procedure using Statview 4.0 (Abacus Concepts, Berkeley, CA, USA). 
A

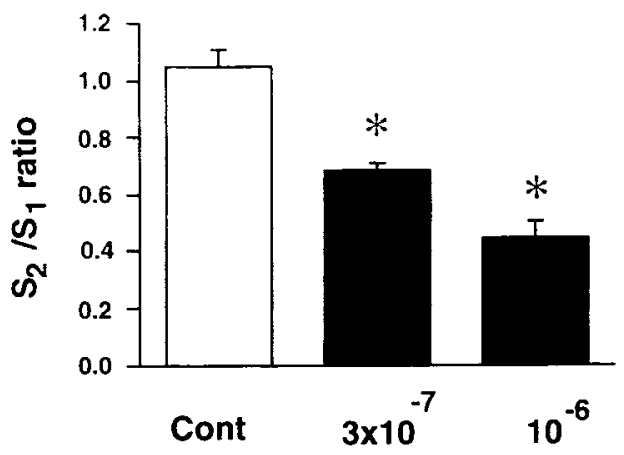

B

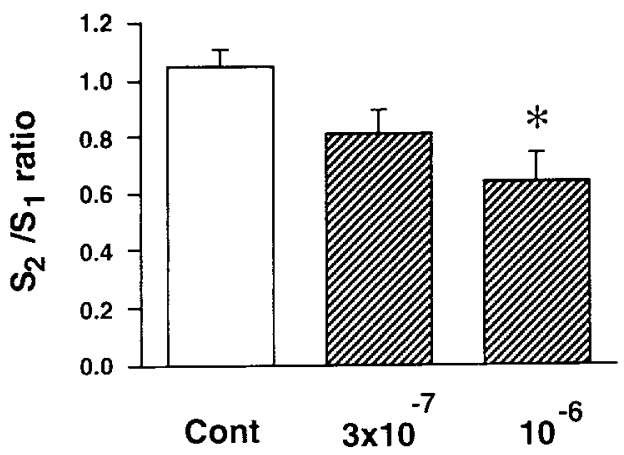

Fig. 2. Effects of endomorphin-1 (A) and endomorphin-2 (B) on the release of $\mathrm{ACh}$ from the isolated rat stomach in vitro. $\mathrm{A}$ : control (cited from Fig. 1A); $3 \times 10^{-7} \mathrm{M}$ endomorphin-1 $(\mathrm{n}=5) ; 10^{-6} \mathrm{M}$ endomorphin-1 $(n=5)$. B: control (cited from Fig. $1 \mathrm{~A}) ; 3 \times 10^{-7} \mathrm{M}$ endomorphin-2 $(n=5) ; 10^{-6} M$ endomorphin-2 $(n=5)$. Other conditions are the same as those in Fig. 1.

and selectivity for $\mu$-receptors and are thought to be natural ligands for this receptor (12). The selectivities of endomorphin- 1 and -2 for the $\mu$-receptor were 4,000 and 13,000 times greater than those for the $\delta$-receptor and 15,000 and 7,000 times greater than those for the $\kappa$-receptor, respectively. Both peptides mediate analgesia in mice after intrathecal injection (13) and mediate hypotensive activity in rabbits after intravenous administration (14). In the present study, endomorphin- $1\left(3 \times 10^{-7}\right.$ and $10^{-6}$ $\mathrm{M})$ and endomorphin-2 $\left(3 \times 10^{-7}\right.$ and $\left.10^{-6} \mathrm{M}\right)$ substantially reduced the release of $\mathrm{ACh}$; the inhibitory effect of endomorphin-1 was more potent than that of endomorphin-2 (Fig. 2). These results further support the conclusion that the $\mu$-receptor is involved in endogenous opioid peptide-induced inhibition of the release of $\mathrm{ACh}$ from the rat stomach.

\section{Acknowledgments}

This work was supported in part by a Grant-in-Aid for Scientific Research (No. 07557315) from The Ministry of Education, Science, Sports and Culture, Japan. We thank Ms. K. Nakamura for her technical assistance.

\section{REFERENCES}

1 Ambinder RF and Schuster MM: Endorphins: new gut peptides with a familiar face. Gastroenterology 77, 1132-1140 (1979)

2 Linnoila RI, DiAugstine RP, Miller RJ, Chang KJ and Cuatrecasas P: An immunohistochemical and radioimmunological study of the distribution of [met $\left.{ }^{5}\right]$ - and [leu $]$-enkephalin in the gastrointestinal tract. Neuroscience 3, 1187-1196 (1978)

3 Yuferov VP, Culpepper-Morgan JA, LaForge KS, Ho A and Kreel MJ: Regional quantitation of preprodynorphin mRNA in guinea pig gastrointestinal tract. Neurochem Res 23, 505511 (1998)

4 DeBold CR, Nicholson WE and Orth DN: Immunoreactive proopiomelanocortin (POMC) peptides and POMC-like messenger ribonucleic acid are present in many rat nonpituitary tissues. Endocrinology 122, 2648-2657 (1988)

5 Nishimura E, Buchan AM and McIntosh $\mathrm{CH}$ : Autoradiographic localization of mu- and delta-type opioid receptors in the gastrointestinal tract of the rat and guinea pig. Gastroenterology 91, 1084-1094 (1986)

6 Fickel J, Bagnol D, Watson SJ and Akil H: Opioid receptor expression in the rat gastrointestinal tract: a quantitative study with comparison to the brain. Brain Res Mol Brain Res 46, 1-8 (1997)

7 Bagnol D, Mansour A, Akil $\mathrm{H}$ and Watson SJ: Cellular localization and distribution of the cloned mu and kappa opioid receptors in rat gastrointestinal tract. Neuroscience 81, 579-591 (1997)

8 Yokotani K, Okuma Y, Nakamura K and Osumi Y: Release of endogenous acetylcholine from a vascularly perfused rat stomach in vitro; inhibition by M3 muscarinic autoreceptors and alpha-2 adrenoceptors. J Pharmacol Exp Ther 266, 1190-1195 (1993)

9 Schoffelmeer ANM, De Vries TJ, Hogenboom F and Mulder $\mathrm{AH}$ : $\mathrm{Mu}$ - and delta-opioid receptors inhibitorily linked to dopamine-sensitive adenylate cyclase in rat striatum display a selectivity profile toward endogenous opioid peptides different from that of presynaptic mu, delta and kappa receptors. J Pharmacol Exp Ther 267, 205-210 (1993)

10 Nakayama S, Taniyama K, Matsuyama S, Ohgushi N, Tsunekawa $\mathrm{K}$ and Tanaka C: Regulatory role of enteric $\mathrm{mu}$ and kappa opioid receptors in the release of acetylcholine and norepinephrine from guinea pig ileum. J Pharmacol Exp Ther 254, 792-798 (1990)

11 Kojima Y, Takahashi T, Fujina $M$ and Owyang C: Inhibition of cholinergic transmission by opiates in ileal myenteric plexus is mediated by kappa receptor. Involvement of regulatory inhibitory G protein and calcium N-channels. J Pharmacol Exp Ther 268, 965-970 (1994)

12 Zadina JE, Hackler L, Ge LJ and Kastin AJ: A potent and selective endogenous agonist for the $\mu$-opiate receptor. Nature 386, 499-502 (1997)

13 Stone LS, Fairbanks CA, Laughlin TM, Nguyen HO, Bushy TM, Wessendorf MW and Wilcox GL: Spinal analgesic actions of the new endogenous opioid peptides endomorphin-1 and -2 . Neuroreport 8, 3131-3135 (1997)

14 Champion HC, Zadina JE, Kastin AJ, Hackler L, Ge L-J and Kadowitz PJ: The endogenous mu-opioid receptor agonists endomorphins 1 and 2 have novel hypotensive activity in the rabbit. Biochem Biophys Res Commun 235, 567-570 (1997) 